\title{
The Preparation and Survival of Almost Bacteria-free Suspensions of Entodinium caudatum
}

\author{
By G. S. COLEMAN \\ Biochemistry Department, Agricultural Research Council Institute \\ of Animal Physiology, Babraham, Cambridge
}

(Received 23 August 1961)

\begin{abstract}
SUMMARY
Suspensions of Entodinium caudatum containing less than one viable bacterium per ten protozoa were prepared by aerobic incubation of the protozoa with penicillin, streptomycin, dihydrostreptomycin and neomycin in the presence of autoclaved rumen fluid and rice starch grains. Unfortunately these almost axenic Entodinia could be maintained alive for only 3-4 days. Replacement of the rice starch grains in the medium used for bacterial removal by soluble starch produced almost bacteria-free protozoa which were devoid of food storage materials and died more rapidly than usual. The life of these protozoa was prolonged by adding any of the following: rice starch grains, soluble starch, maltose, glucose and some other sugars.
\end{abstract}

\section{INTRODUCTION}

Sheep rumen Entodiniomorphid (Oligotrich sensu lato of Corliss, 1959) protozoa, principally Entodinium caudatum, have been maintained dividing every 2 days in the presence of bacteria for over 18 months (Coleman, 1960 a). There are two reports in the literature of successful attempts to prepare axenic Entodiniomorphid protozoa (Sugden, 1953; Abou Akkada \& Howard, 1960), but in each case the demonstration that bacteria were absent depended on the use of a single growth medium. Oxford (1958) treated Epidinium ecaudatum with penicillin and neomycin but was unable to obtain the protozoa free from bacteria. The present paper records a successful attempt to obtain almost bacteria-free protozoa, many media being used to test for the absence of bacteria. The protozoa were first incubated with antibiotics to decrease the number of bacteria and then the effects of various incubation conditions on the survival of these protozoa were studied.

\section{METHODS}

Source of protozoa. The original source of the protozoa was described previously (Coleman, 1958, 1960 a) and when used they had been grown on rice starch, grass, autoclaved rumen fluid and chloramphenicol under condition C3 (Coleman, 1960 a) for over a year. However, whilst most of the experiments described below were being carried out this routine procedure was simplified as follows. The protozoa were grown in $250 \mathrm{ml}$. centrifuge tubes containing $150 \mathrm{ml}$. medium and $30 \mathrm{mg}$. rice starch and about $50 \mathrm{mg}$. dried grass were added each day. Twice a week two-thirds of the supernatant fluid was sucked off as quickly as possible and replaced by fresh medium (salt solution; Coleman, 1958) to which was added per $100 \mathrm{ml}$. : $10 \mathrm{ml}$. auto- 
claved rumen fluid (ARF), $5 \mathrm{mg}$. chloramphenicol, $25 \mathrm{mg}$. rice starch and about $100 \mathrm{mg}$. dried grass). After mixing, the culture was divided into two, and one half was made up to the original volume with fresh medium and continued as the stock culture. The other half was combined with a similar half from another culture tube and placed in two $100 \mathrm{ml}$. centrifuge tubes (to facilitate subsequent manipulations) to form an 'inoculum culture'. These culture tubes were treated each day with $22 \mathrm{mg}$. rice starch and about $20 \mathrm{mg}$. dried grass and used on the third day as the source of protozoa. Under these conditions the protozoa formed a white layer at the bottom of the tube and the grass remained as a scum on the surface.

Treatment to remove bacteria from protozoal suspensions. The standard procedure finally adopted is as follows. The medium consisted of $3 \mathrm{ml}$. salt solution B (Coleman, $1960 \mathrm{~b}$ ) autoclaved $\left(115^{\circ}\right.$ for $20 \mathrm{~min}$.) in a cotton plugged $5 \mathrm{in} . \times \frac{1}{2}$ in. test tube. Immediately after removal from the autoclave and cooling the following additions were made aseptically: $0.2 \mathrm{ml} .1 \%(\mathrm{w} / \mathrm{v})$ L-cysteine hydrochloride (neutralized with $\mathrm{NaOH}$ and Seitz-filtered just before use), $0.2 \mathrm{ml} .5 \%(\mathrm{w} / \mathrm{v}) \mathrm{NaHCO}_{3}, 0.1 \mathrm{ml}$. $6 \%(\mathrm{w} / \mathrm{v})$ rice starch (British Drug Houses Ltd., Poole, heated at $120^{\circ}$ for $24 \mathrm{hr}$. ), $0.4 \mathrm{ml}$. penicillin G $(25,000 \mathrm{units} / \mathrm{ml}),. 0.4 \mathrm{ml} .1 \%(\mathrm{w} / \mathrm{v})$ streptomycin sulphate solution, $0.4 \mathrm{ml} .1 \%(\mathrm{w} / \mathrm{v})$ dihydrostreptomycin sulphate solution, $0.4 \mathrm{ml} .1 \%$

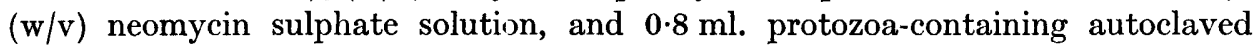
rumen fluid (PARF). The antibiotics were dissolved in salt solution $\mathbf{B}$. Where larger quantities of 'bacteria-free' protozoa were required, as in the experiments on the subsequent survival of these protozoa, five times the above quantities were taken in $15 \mathrm{~cm} . \times 2 \cdot 2 \mathrm{~cm}$. tubes.

The protozoa were taken from the inoculum cultures, after removal of the surface scum and most of the supernatant liquid, and allowed to stand in a suitable test tube for 2 min. until any grass present had sunk to the bottom. The supernatant fluid containing the protozoa was transferred to centrifuge tubes, the residual grass washed once with salt solution $B$ and then the protozoa washed five times in salt solution B which contained $0 \cdot 3 \%(\mathrm{w} / \mathrm{v})$ yeast extract and $0 \cdot 03 \%(\mathrm{w} / \mathrm{v})$ L-cysteine on an angle-head centrifuge at $400 \mathrm{~g}$ for $1 \mathrm{~min}$. They were finally inoculated at a population density of $30,000-80,000$ protozoa $/ \mathrm{ml}$. incubation medium, the culture well mixed and incubated aerobically at $39^{\circ}$ for 3 days.

Incubation conditions for 'bacteria-free' protozoa. Under standard conditions the medium consisted of 1-4 ml. (adjusted so that the final volume was $7 \cdot 6 \mathrm{ml}$.) salt solution B (Coleman, $1960 \mathrm{~b})$ autoclaved $\left(115^{\circ}\right.$ for $20 \mathrm{~min}$.) with $0.9 \mathrm{ml}$. water and $0.4 \mathrm{ml} .0 .05 \mathrm{M}-\mathrm{DL}-p$-fluorophenylalanine in a $5 \mathrm{in} . \times \frac{1}{2} \mathrm{in}$. cotton-plugged test tube or $7.5 \mathrm{ml}$. tube (fitted with a ground glass stopper). Immediately after removal from the autoclave and cooling the following additions were made aseptically: $0 \cdot 2 \mathrm{ml}$. $1 \%(\mathrm{w} / \mathrm{v})$ L-cysteine hydrochloride (neutralized and Seitz filtered), $0.1 \mathrm{ml} .6 \%$ $(\mathrm{w} / \mathrm{v})$ rice starch, $0.4 \mathrm{ml}$. penicillin $\mathrm{G}(25,000 \mathrm{units} / \mathrm{ml}$.), $0.4 \mathrm{ml} .1 \%(\mathrm{w} / \mathrm{v})$ strepto-

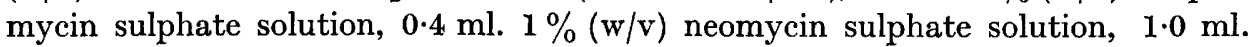
Seitz-filtered rumen fluid and any other additions. The 5 in. $\times \frac{1}{2}$ in. test tubes were gassed with $95 \%(\mathrm{v} / \mathrm{v}) \mathrm{N}_{2}+5 \%(\mathrm{v} / \mathrm{v}) \mathrm{CO}_{2}$ for $1 \frac{1}{2}$ min. and then sealed with a sterile rubber bung. Except where stated, all experiments were carried out in these tubes which were inoculated by opening momentarily and then regassing with $95 \%(\mathrm{v} / \mathrm{v})$ $\mathrm{N}_{2}+5 \%(\mathrm{v} / \mathrm{v}) \mathrm{CO}_{2}$. The $7 \cdot 5 \mathrm{ml}$. glass-stoppered tubes were inoculated before completely filling with sterile salt solution $\mathrm{B}$ and sealing with a flamed glass stopper. 
The protozoa for inoculation were prepared from the bacterial removal (or first) incubation medium by sucking off $80-90 \%$ of the supernatant fluid (this removed no protozoa) and washing the sedimented protozoa twice on the centrifuge with salt solution B plus $0 \cdot 03 \%(\mathrm{w} / \mathrm{v})$ L-cysteine solution.

Sterile rumen fluid fractions. All rumen fluid was taken from Chn Forest wethers fed on hay or hay and oats. Protozoa-containing autoclaved rumen fluid (PARF) was prepared from fresh rumen contents by straining through two layers of muslin and autoclaving under $95 \%(\mathrm{v} / \mathrm{v}) \mathrm{N}_{2}+5 \%(\mathrm{v} / \mathrm{v}) \mathrm{CO}_{2}$ in sealed McCartney bottles at $115^{\circ}$ for $20 \mathrm{~min}$. Autoclaved rumen fluid (ARF) was prepared similarly to PARF except that the strained material was subsequently centrifuged at $500 \mathrm{~g}$ for $\mathbf{3}$ min. before autoclaving. Autoclaved supernatant rumen fluid was prepared similarly to PARF except that the strained material was centrifuged at $12,000 \mathrm{~g}$ for $45 \mathrm{~min}$. before autoclaving. Autoclaved rumen bacteria fraction was the pellet from the above $12,000 \mathrm{~g}$ centrifugation, washed once on the centrifuge in salt solution $\mathrm{B}$, and made up to the original volume before autoclaving. Seitz-filtered rumen fluid was prepared as autoclaved supernatant rumen fluid except that sterilization was effected by Seitz-filtration. The number of protozoa was estimated by the method of Coleman (1958). Only those protozoa which showed no signs of distintegration were counted.

All gases were freed from oxygen by the method of Stone \& Beeson (1936).

Bacterial culture media. Medium A contained (g./100 ml.): $\mathrm{K}_{2} \mathrm{HPO}_{4}, 0.50$; $\mathrm{KH}_{2} \mathrm{PO}_{4}, 0.39 ; \mathrm{NaCl}, 0 \cdot 050 ; \mathrm{MgSO}_{4} 7 \mathrm{H}_{2} \mathrm{O}, 0.007 ; \mathrm{CaCl}_{2} 6 \mathrm{H}_{2} \mathrm{O}, 0.007$; Difco yeast extract, 0.5; Difco Bacto-tryptose, 0.5; glucose, 0.5; sodium lactate, 0.35; $4 \mathrm{ml}$. PARF (centrifuged to remove solid matter) autoclaved at $115^{\circ}$ for $20 \mathrm{~min}$. Medium A was always incubated aerobically in cotton-plugged tubes.

Medium B was Oxoid (Oxo Ltd., London, E.C. 4) thioglycollate (fluid) medium (fluid thioglycollate medium U.S.P.) to which was added $10 \%(\mathrm{v} / \mathrm{v})$ PARF (centrifuged to remove solid matter) dispensed in $5 \mathrm{ml}$. quantities in $5 \mathrm{in} . \times \frac{1}{2}$ in. tubes. After inoculation a half-inch layer of sterile liquid paraffin was run on the surface of the medium and the tubes incubated in an anaerobe jar under $95 \%(\mathrm{v} / \mathrm{v})$ $\mathrm{H}_{2}+5 \%(\mathrm{v} / \mathrm{v}) \mathrm{CO}_{2}$.

Medium C was based on that of Bryant \& Robinson (1961) and contained per $100 \mathrm{ml}$.: $40 \mathrm{ml}$. PARF (centrifuged to remove solid matter); $0.5 \mathrm{~g}$. agar (Davis Gelatine Co. Ltd., London E.C. 3); $0 \cdot 1 \mathrm{ml} .0 \cdot 1 \%$ resazurin; $3.75 \mathrm{ml}$. each mineral salt solutions no. 1 and no. 2 (Bryant \& Burkey, 1953); 0.025 g. glucose; 0.025 g. cellobiose; $0.05 \mathrm{~g}$. soluble starch; water to $100 \mathrm{ml}$. This was autoclaved $\left(115^{\circ}\right.$ for $20 \mathrm{~min}$.) in $5 \mathrm{ml}$. quantities in $5 \mathrm{in} . \times \frac{1}{2}$ in. tubes and after cooling to $50^{\circ} 0.25 \mathrm{ml}$. sterile $8 \%(\mathrm{w} / \mathrm{v}) \mathrm{Na}_{2} \mathrm{CO}_{3}$ and $0.25 \mathrm{ml}$. of a mixture of $0.5 \%(\mathrm{w} / \mathrm{v})$ L-cysteine and $0 \cdot 5 \%(\mathrm{w} / \mathrm{v}) \mathrm{Na}_{2} \mathrm{~S} .9 \mathrm{H}_{2} \mathrm{O}$ (autoclaved together under $\mathrm{N}_{2}$ after adjustment to $\mathrm{pH} 11$ ) were added and the medium gassed with $\mathrm{CO}_{2}$ for $1 \frac{1}{2} \mathrm{~min}$.

Bacterial viable counts. The standard technique for determining the number of viable bacteria in 'bacteria-free' protozoal suspensions treated under standard conditions was as follows : $\mathbf{0} \cdot \mathbf{1} \mathrm{ml}$. of a well mixed suspension was added to $5 \mathrm{ml}$. medium $B$ and then $0.05 \mathrm{ml}$. of this diluted suspension inoculated into media $\mathbf{A}$, $\mathrm{B}$ and $\mathrm{C}$ followed by two serial tenfold dilutions in media $\mathrm{A}$ and $\mathrm{B}$. Each colony in medium $\mathrm{C}$ represented $10^{3}$ bacteria $/ \mathrm{ml}$. of the original suspension. Where more bacteria were present serial dilutions were made in medium $\mathrm{B}$ before inoculation 
into media $\mathbf{A}$ and $\mathrm{C}$. None of the media maintained the inoculated living protozoa which disintegrated and liberated their ingested bacteria.

All cultures were incubated at $30^{\circ}$ for at least 10 days.

\section{RESULTS}

Suspensions of Entodinium caudat :m $\left(10^{4}-10^{5}\right.$ protozoa $/ \mathrm{ml}$.) prepared from growing cultures as described above by washing five times still contained over $10^{6}$ bacteria/ ml., excluding those in the gastric sac. Breakage of the protozoa in a Potter homogenizer to liberate these internal bacteria increased the bacterial count 10-100 times on all media. It was therefor : necessary to remove most of these internal and external bacteria before it was possible to study the survival and metabolism of the protozoa. A maximum limit of on: viable bacterium per ten intact protozoa was arbitrarily chosen; any experiments in which the 'bacteria-free' protozoa contained more bacteria than this were discarded. To demonstrate that the bacteria had been removed it was first essential to grow all the bacteria present; some experiments on the production of media able to "rrow the bacteria in antibiotic-treated protozoal suspensions are described below.

\section{Media for bacterial viable counts}

Preliminary experiments on the development of media $\mathrm{A}, \mathrm{B}$ and $\mathrm{C}$ to give the highest bacterial viable counts wer 2 carried out on crude rumen contents and on penicillin-treated protozoa (Coleman, 1960 b). Subsequent experiments on protozoal cultures treated under standard conditions confirmed that media $\mathrm{A}, \mathrm{B}$ and $\mathrm{C}$ gave higher results than other media tested.

For an aerobic viable count medium A grew $10^{8}$ bacteria $/ \mathrm{ml}$. crude rumen fluid and $10^{7}$ bacteria/ml. of growing protozo al cultures. Medium A grew more bacteria from antibiotic-treated protozoal suspensions than did medium B, Oxoid thioglycollate medium (Brewer), Oxoid thioglycol ate (fluid) medium, Oxoid reinforced clostridial medium or glucose peptone water incubated aerobically. The addition of $0.05 \%$ $(\mathrm{w} / \mathrm{v})$ L-cysteine to medium $\mathrm{A}$ and incubation in an anaerobe jar under $95 \%(\mathrm{v} / \mathrm{v})$ $\mathrm{H}_{2}+5 \%(\mathrm{v} / \mathrm{v}) \mathrm{CO}_{2}$ decreased bacterial count. Solidification of medium A with $1 \%(\mathrm{w} / \mathrm{v})$ Davis agar and incubation aerobically in plates produced no colonies although liquid medium inoculated with the same inoculum grew well. Growth in medium A always began on the surface and sometimes spread throughout the medium.

Media $\mathrm{B}$ and $\mathrm{C}$ were used routinely for the growth of anaerobes. They grew respectively $10^{8}-10^{9}$ and $10^{9}-10^{10}$ bacteria/ml. crude rumen contents and $10^{7}-10^{8}$ and $10^{8}-10^{9}$ bacteria $/ \mathrm{ml}$. growing proto zoal cultures. Omission of PARF or agar from medium $B$ decreased the bacterial count in penicillin and streptomycin-treated suspensions from, for example, $10^{5}$ to $10^{2}$. The number of colonies produced on medium B solidified with agar was at best $25-50 \%$ of those in medium $\mathrm{C}$ and they were almost too small to count under a lens. Medium B grew more bacteria than Oxoid reinforced clostridial mediunı; neither medium was improved by the addition of $0.1 \%(\mathrm{w} / \mathrm{v})$ maltose, cellobiose (r $0.5 \%(\mathrm{w} / \mathrm{v})$ sodium lactate.

There was always a $24-36 \mathrm{hr}$. lag before there was visible bacterial growth on any 
medium after inoculation from antibiotic-treated suspensions although rumen fluid inoculations grew overnight. All viable count cultures were incubated for 10 days because there was occasionally a 7-day lag before growth began.

\section{Preparation of almost bacteria-free Entodinia}

Table 1 shows that to obtain protozoa probably contaminated with less than $10 \%$ of their number of bacteria it was necessary to incubate aerobically in the presence of penicillin + streptomycin + dihydrostreptomycin + neomycin. The addition of dried grass and yeast extract increased the number of surviving protozoa when penicillin $($ Coleman, $1960 b)$ or penicillin + streptomycin were present, but with the four anti-

Table 1. The effect of various antibiotics and of aerobic incubation conditions on protozoal survival and the removal of bacteria

Experiment carried out either anaerobically in completely filled and sealed $7.5 \mathrm{ml}$. tubes or aerobically in cotton plugged 5 in. $\times \frac{1}{2}$ in. test tubes containing $7 \cdot 4 \mathrm{ml}$. liquid. The inoculum was prepared as described in the text and all tubes were incubated for 3 days. All the tubes contained salts, $0.03 \%(\mathrm{w} / \mathrm{v})$ L-cysteine, $0 \cdot 15 \%(\mathrm{w} / \mathrm{v}) \mathrm{NaHCO}_{3}$, $0 \cdot 17 \%(\mathrm{w} / \mathrm{v})$ rice starch, 1400 units penicillin $/ \mathrm{ml}$. and $12 \%(\mathrm{v} / \mathrm{v})$ PARF. The numbers of viable bacteria are those that grew on media $A, B$ and $C$ respectively.

\begin{tabular}{|c|c|c|c|}
\hline $\begin{array}{l}\text { Aerobic or } \\
\text { anaerobic }\end{array}$ & $\begin{array}{c}\text { Additional } \\
\text { antibiotics* }\end{array}$ & Protozoa $/ \mathrm{ml}$. & Bacteria $/ \mathrm{ml}$. \\
\hline Initial & & 38,000 & $10^{6}, 10^{6}, 7 \times 10^{6}$ \\
\hline Anaerobic & None & 40,000 & $10^{5},>10^{6}, 10 \times 10^{7}$ \\
\hline Anaerobic & Str & 40,000 & $10^{4}, 10^{4}, 10^{6}$ \\
\hline Aerobic & Str & 26,000 & $10^{3}, 10^{3}, 20 \times 10^{5}$ \\
\hline Aerobic & Str, Dhs, Neo & 12,000 & $10^{3}, 10^{3}, 1 \times 10^{3}$ \\
\hline Anaerobic & Str, Dhs, Neo & 21,000 & $10^{4},<10^{3}, 80 \times 10^{3}$ \\
\hline Aerobic & Neo & 17,800 & $10^{3}, 10^{3}, 3 \times 10^{3}$ \\
\hline Aerobic & Str, Neo & 16,500 & $10^{3}, 10^{3}, 3 \times 10^{3}$ \\
\hline Aerobic & Dhs, Neo & 15,000 & $10^{3}, 10^{3}, 4 \times 10^{3}$ \\
\hline Aerobic & Str, Dhs & 27,000 & $10^{3}, 10^{4}, 250 \times 10^{3}$ \\
\hline Aerobic & No penicillin & 10,000 & $>10^{8}, 10^{9}, ?$ \\
\hline
\end{tabular}

$* \mathrm{Str}=\mathbf{5 7 0} \mu \mathrm{g}$. streptomycin sulphate $/ \mathrm{ml}$. Dhs $=\mathbf{5 7 0} \mu \mathrm{g}$. dihydrostreptomycin sulphate $/ \mathrm{ml}$.; $\mathrm{Neo}=\mathbf{5 7 0} \mu \mathrm{g}$. neomycin sulphate $/ \mathrm{ml}$.

biotics together they only increased the number of bacteria. The omission of the antibiotics singly or in pairs showed that penicillin + neomycin were almost as effective as the four antibiotics together (Table 1). Sodium propionate was added routinely to media (in salt solution B) to suppress the growth of moulds (Mrak \& Phaff, 1948).

To ensure adequate survival of the protozoa it was essential to add $12 \%(\mathrm{v} / \mathrm{v})$ PARF to the incubation medium (Table 2). Other rumen fluid fractions and lower or higher concentrations of PARF were less effective in producing the largest possible number of 'bacteria-free' protozoa.

Figure 1 shows a time course for incubation under aerobic and anaerobic conditions. Although in about half the experiments the same final result was obtained under both conditions, the anaerobic incubation was not used routinely since an extra day was required and frequently the aerobic bacterial count (medium A) was too high.

Since the number of viable bacteria was determined on suspensions of intact protozoa it was possible for the results obtained to be low, since each protozoan that 
contained one or more bacteria would give rise to only one colony in the assay. However, breakage of the 'bacteria free' protozoa in a Potter homogenizer before diluting the suspension to deterraine the number of viable bacteria did not increase the number of bacteria that grew on media $\mathrm{A}$ or $\mathrm{C}$. This shows, within the limits of the method, that if a protozoan contained bacteria it contained only one bacterium.

\section{Table 2. The effect of zarious rumen fluid fractions on protozoal survival and the removal of bacteria}

Experiment carried out in cotton plugged 5 in. $\times \frac{1}{2}$ in. test tubes containing $7 \cdot 4 \mathrm{ml}$. medium incubated aerobically for 3 days. All tubes contained the standard incubation medium used for bacterial removal except that the PARF was replaced by various rumen fluid fractions as indicated below. The numbers of viable bacteria are those that grew on media A, B and C respectively. The initial number of protozoa was $40,000 / \mathrm{ml}$.

Rumen fluid fraction

\section{None}

$3 \%(v / v)$ PARF

$12 \%(v / v)$ PARF

$30 \%(v / v)$ PARF

$12 \%(v / v)$ Seitz-filtered rumen fluid

$12 \%(v / v)$ ARF

$12 \%(v / v)$ autoclaved supernatant rumen fluid
Protozoa $/ \mathrm{ml}$.

2,900

11,600

15,400

19,400

$\mathbf{9 , 5 0 0}$

8,700

11,600

Bacteria/ml.

$10^{4}, 10^{3}, 10^{3}$

$10^{4}, 10^{\mathrm{s}},<10^{3}$

$10^{3}, 10^{3},<10^{3}$

$10^{3},<10^{3}, 150 \times 10^{3}$

$10^{3},<10^{3},<10^{3}$

$10^{3}, 10^{3}, 1 \times 10^{3}$

$10^{4}, 10^{3},<10^{3}$

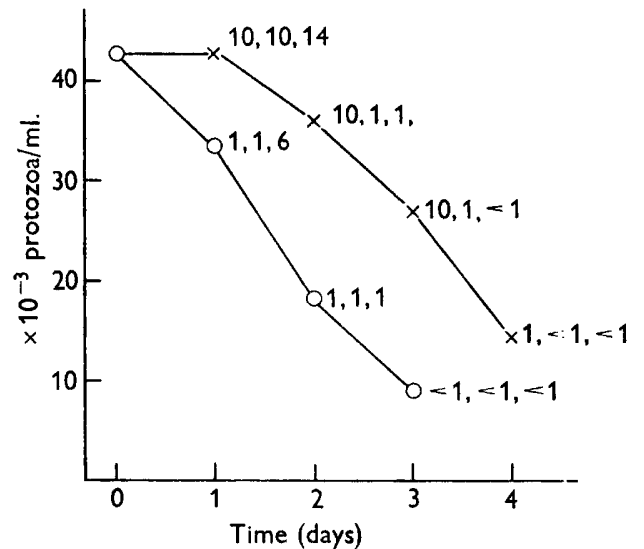

Fig. 1

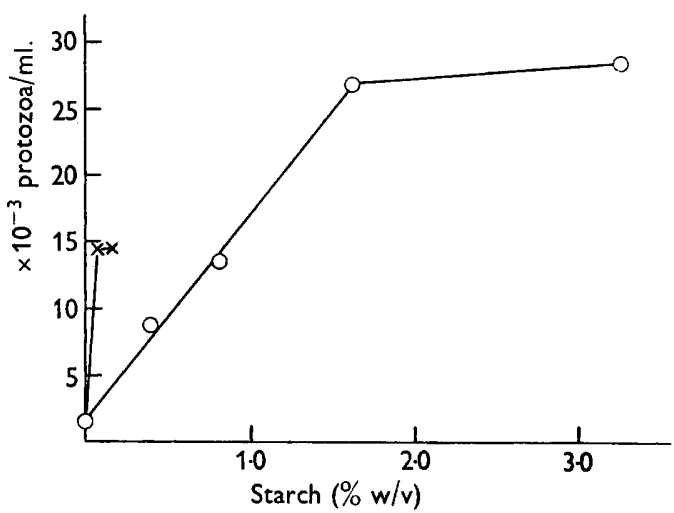

Fig. 2

Fig. 1. Effect of incubation time on the survival of protozoa and the disappearance of bacteria during the incubation used for bacterial removal. $O-O$, Incubation under aerobic conditions; $x-x$, incubation under anaerobic conditions. The figures at each point refer to the number of bacteria (in thousands) that grew on media $A, B$ and $C$ respectively.

Fig. 2. Effect of starch concentration on the survival of protozoa under otherwise standard conditions during the incubation used for bacterial removal. Duration of experiment was 3 days and the initial number of protozoa $60,000 / \mathrm{ml}$. $\bigcirc-\bigcirc$, Soluble starch; $\times-\times$, rice starch grains.

\section{Replacement of the rice starch grains by soluble starch}

For these experiments protozoa, the gastric sacs of which contained only a few rice starch grains, were prepared by the addition of only $5 \mathrm{mg}$. rice starch to the inoculum cultures on the day before that on which the protozoa were required. 
Figure 2 shows that in the absence of starch less than $5 \%$ of the protozoa survived after 3 days and that the addition of up to $1 \cdot 6 \%$ soluble starch linearly increased the number of survivors. Although ten times more soluble starch than rice starch grains was required to obtain the same survival, the maximum number was double that in the presence of rice starch grains. Unfortunately in half the experiments $10^{4}-10^{5}$ bacteria/ml. survived in the presence of soluble starch. In contrast to the protozoa incubated with $0 \cdot 04-0.08 \%(\mathrm{w} / \mathrm{v})$ rice starch grains or $1 \cdot 6-3 \cdot 2 \%(\mathrm{w} / \mathrm{v})$ soluble starch, those which survived in the presence of $0-0.8 \%(\mathrm{w} / \mathrm{v})$ soluble starch contained no material which stained blue with iodine. These latter protozoa when incubated under the second incubation conditions in the absence of carbohydrate died more quickly than normal protozoa full of rice starch grains and the effect of carbohydrates on their survival could be studied.

\section{The survival of bacteria-free Entodinia}

It did not prove possible to maintain the normal 'bacteria-free' protozoa alive for longer than 3-4 days; the numbers steadily declined throughout this period. Nevertheless, various factors influenced the rate at which the organisms died. To obtain maximum survival of the protozoa it was necessary to decrease to a minimum the manipulations of the organisms after removal from the first incubation medium. The best results were obtained by sucking off the supernatant fluid from the first incubation and inoculating the residual protozoa directly into new medium. As the object of the work was to study the effect of various substances on the survival and metabolism of the protozoa, these were usually washed twice before inoculation. Under these conditions damage to the organisms, as measured by the decrease in the number of living protozoa over the first $6 \mathrm{hr}$., was $20 \%$ as compared with $10 \%$ for unwashed protozoa; subsequently the rate of decrease was the same for both cultures.

The lowest effective concentration of L-cysteine was $0.03 \%(w / v)$. Omission of the L-cysteine decreased the number of survivors after $24 \mathrm{hr}$. by over $60 \%$ and an increase in concentration to $0 \cdot 15 \%(\mathrm{w} / \mathrm{v})$ had no additional effect.

Omission of the antibiotics singly or all together did not usually result in bacterial growth during the first $24 \mathrm{hr}$., but the number of protozoa decreased by $5-20 \%$. DL- $p$-Fluorophenylalanine $\left(2 \cdot 6 \times 10^{-3} \mathrm{M}\right)$ was routinely used in this second incubation medium to suppress the growth of bacteria which subsequently grew specifically on medium $\mathrm{C}$. In the absence of $p$-fluorophenylalanine these bacteria were found in about half the experiments where nutrient materials were added in an attempt to stimulate the protozoa. $p$-Fluorophenylalanine in concentrations up to $0.005 \mathrm{M}$ had no effect on the survival of the protozoa whether bacteria grew in its absence or not.

Effect of $\mathrm{CO}_{2}$ and rumen fluid fractions. Seitz-filtered rumen fluid was more effective than other rumen fluid fractions tested in maintaining 'bacteria-free' protozoa alive (Table 3). The survival in the absence of Seitz-filtered rumen fluid was variable when experiments were carried out in sealed tubes or under $100 \% \mathrm{~N}_{2}$ but more consistent results were obtained with $5 \%(\mathrm{v} / \mathrm{v}) \mathrm{CO}_{2}$ in the gas phase. In those experiments in sealed tubes with poor survival in the absence of Seitz-filtered rumen fluid, $5 \%(\mathrm{v} / \mathrm{v}) \mathrm{CO}_{2}$ was stimulatory in the presence of $0-14 \%(\mathrm{v} / \mathrm{v})$ but not with $42 \%(\mathrm{v} / \mathrm{v})$ Seitz-filtered rumen fluid. An increase in the $\mathrm{CO}_{2}$ to $100 \%$ (plus 
the addition of $0.4 \%(\mathrm{w} / \mathrm{v}) \mathrm{Na}_{2}\left(\mathrm{O}_{3}\right.$ to maintain the $\mathrm{pH}$ value constant) had no further stimulatory effect (Table 3). The addition of $0 \cdot 14 \%(\mathrm{w} / \mathrm{v}) \mathrm{NaHCO}_{3}$ to the sealed tube experiments gave similar results to gassing the medium with $95 \%(\mathrm{v} / \mathrm{v})$ $\mathrm{N}_{2}+5 \%(\mathrm{v} / \mathrm{v}) \mathrm{CO}_{2}$.

\title{
Table 3. The effect of carbon dioxide and rumen fluid fractions on protozoal survival during the second incubation
}

\begin{abstract}
Experiment carried out either anaerobically in 5 in. $\times \frac{1}{2}$ in. test tubes containing $7.4 \mathrm{ml}$. medium under the appropriate gas or in completely filled and sealed tubes containing $7.5 \mathrm{ml}$. medium incubated for $24 \mathrm{hr}$. The standard inoculum and medium was used except where the carbon dioxide tension or rumen fluid fraction was varied. Where $100 \% \mathrm{CO}_{2}$ was present, $0 \cdot 4 \%(\mathrm{w} / \mathrm{v}) \mathrm{Na}_{2} \mathrm{CO}_{3}$ was added to the medium.
\end{abstract}

\begin{tabular}{|c|c|c|}
\hline $\mathrm{CO}_{2}$ added & Rumen fluid fraction & $\begin{array}{c}\text { Number of protozo } \\
\text { relative to } \\
\text { initial }=100\end{array}$ \\
\hline None* & None & 20 \\
\hline None* & $14 \%(v / v)$ Seitz-filtered & 36 \\
\hline None* & $42 \%(v / v)$ Seitz-filtered & 50 \\
\hline $5 \% \dagger$ & None & 42 \\
\hline $5 \% \dagger$ & $14 \%(v / v)$ Seitz-filtered & 65 \\
\hline $5 \% \dagger$ & $42 \%(v / v)$ Seitz-filtered & 49 \\
\hline $100 \%$ & None & 40 \\
\hline $100 \%$ & $14 \%(v / v)$ Seitz- iltered & 68 \\
\hline $5 \% \dagger$ & $14 \%(v / v)$ PARF & 54 \\
\hline $5 \% \dagger$ & $14 \%(v / v)$ ARF & 52 \\
\hline $5 \% \dagger$ & $14 \%(\mathrm{v} / \mathrm{v})$ Autoclaved supernatant & 56 \\
\hline $5 \% \dagger$ & $14 \%(v / v)$ Autoclaved rumen bacteria & 40 \\
\hline
\end{tabular}

Although Abou Akkada \& Howard (1960) found that salt solutions buffered only with phosphate were harmful to their Entodinia no such effect was noticed in the present studies. Under otherwise standard conditions salt solution B was $\mathbf{1 0 - 2 0 \%}$ more effective in the maintenance of the protozoa than was the same solution when the sodium propionate was omitted and the concentration of the other constituents increased to maintain the osmotic pressure, or when propionate was replaced by an equimolar amount of sodium acetate or by $0.1 \%(\mathrm{w} / \mathrm{v}) \mathrm{NaHCO}_{3}$. Similar results were obtained with growing protozoa (Coleman, 1958, 1960 $a$ ) where sodium acetate could be omitted without harming the protozoa.

Effect of various additives on protozoal survival. None of the following substances at the concentrations indicated prolonged the life of the protozoa incubated under standard conditions : $0 \cdot 03-0 \cdot 15 \%(\mathrm{v} / \mathrm{v})$ agar (Davis); $0.0005 \mathrm{M}-\mathrm{NH}_{4} \mathrm{Cl} ; 0 \cdot 3 \%(\mathrm{w} / \mathrm{v})$ Bacto-peptone (Difco); $0.3 \%$ (w/v) Bacto-tryptose; a mixture of $0 \cdot 1-100 \mu \mathrm{g} . / \mathrm{ml}$. each of $i s o b u t y r i c$ acid, valeric acid and isovaleric acid (found by Wegner $\&$ Foster, 1960, to stimulate certain rumen kacteria); $0.3 \%(\mathrm{w} / \mathrm{v})$ Casamino acids (Difco); $0.1 \%(\mathrm{w} / \mathrm{v})$ casein; $0.14 \%(\mathrm{w} / \mathrm{v})$ cellobiose; $0.001-0.01 \%(\mathrm{w} / \mathrm{v})$ cholesterol; $0.14 \%$ $(\mathrm{w} / \mathrm{v})$ glucose; a mixture of eleven growth factors $(0 \cdot 1-0.5 \mu \mathrm{g} . / \mathrm{ml}$. each of $p$-aminobenzoic acid, $\beta$-alanine, biotin, calcium pantothenate, folic acid, nicotinic acid, nicotinamide, pyridoxin, riboflavin, thiamine, vitamin $\left.B_{12}\right) ; 0.01 \%(\mathrm{w} / \mathrm{v})$ haematin; $5 \%(\mathrm{v} / \mathrm{v})$ horse serum; $0.005 \mathrm{M}$-DL-lactate; $0.3 \%(\mathrm{w} / \mathrm{v})$ malt extract; 
$0 \cdot 14 \%(\mathrm{w} / \mathrm{v})$ maltose; $1 \%(\mathrm{v} / \mathrm{v})$ milk (fresh); $0.3 \%$ Tryptone; $0.01-0.1 \%(\mathrm{w} / \mathrm{v})$ Tween $80 ; 7-20 \%(\mathrm{v} / \mathrm{v})$ tomato juice; $0.003-0.3 \%(\mathrm{w} / \mathrm{v})$ yeast extract (Difco or Oxoid).

Replacement of rice starch grains by other carbohydrates. For these experiments the protozoa were prepared under standard conditions except that on the day before

Table 4. The effect of various carbohydrates on the survival of 'bacteria-free' Entodinia

Experiment carried out in sealed 5 in. $\times \frac{1}{2}$ in. test tubes under $95 \%(v / v) N_{2}+5 \%(v / v)$ $\mathrm{CO}_{2}$ in the presence of $13 \%(\mathrm{v} / \mathrm{v})$ Seitz-filtered rumen fluid. The protozoa differed from those used in other experiments in that they were rendered bacteria-free by incubation in a medium containing soluble starch instead of rice starch and contained no iodinestaining intracellular material. For exact conditions see text.

\section{Carbohydrate}

$0 \cdot 3-1 \cdot 0 \%$ Soluble starch

$0.08 \%$ Rice starch

1.0\% Amylose

$1.0 \%$ Amylopectin

$\mathbf{0 . 4} \%$ Inulin

$0.4 \%$ Dextrin

$1.3 \%$ Arabinose

$\mathbf{1 . 6} \%$ Fructose

$1.6 \%$ Galactose

$1.6 \%$ Glucose

$1.6 \%$ Mannose

\section{Number of survivors after $24 \mathrm{hr}$.*}

$1 \cdot 00$
$0 \cdot 4-0 \cdot 8$
$0 \cdot 8$
$0 \cdot 9$
$0 \cdot 05$
$0 \cdot 5$
$0 \cdot 1$
$0 \cdot 2$
$-0 \cdot 6$
$0 \cdot 5-0 \cdot 9$
$0 \cdot 1$

\section{Number of survivors after $\mathbf{2 4}$ hr.*}

$\mathbf{1 . 3} \%$ Sorbose
$\mathbf{1 . 3} \%$ Xylose
$\mathbf{1 . 3} \%$ Sorbitol
$\mathbf{1 . 6} \%$ Cellobiose
$\mathbf{1 . 3} \%$ Lactose
$\mathbf{1 . 6} \%$ Maltose
$\mathbf{1 . 3} \%$ Melibiose
$\mathbf{1 . 6} \%$ Sucrose
$\mathbf{1 . 3} \%$ Salicin
$\mathbf{1 . 3} \%$ Raffinose

0

0.5

$0 \cdot 2$

$0 \cdot 3$

$0 \cdot 1$

$0 \cdot 7-1 \cdot 0$

0.5

$0 \cdot 6$

0

$0 \cdot 1$

* The results are quoted as (survivors in presence of carbohydrate-survivors in absence of (arbohydrate)/(survivors in presence of soluble starch - survivors in absence of carbohydrate).

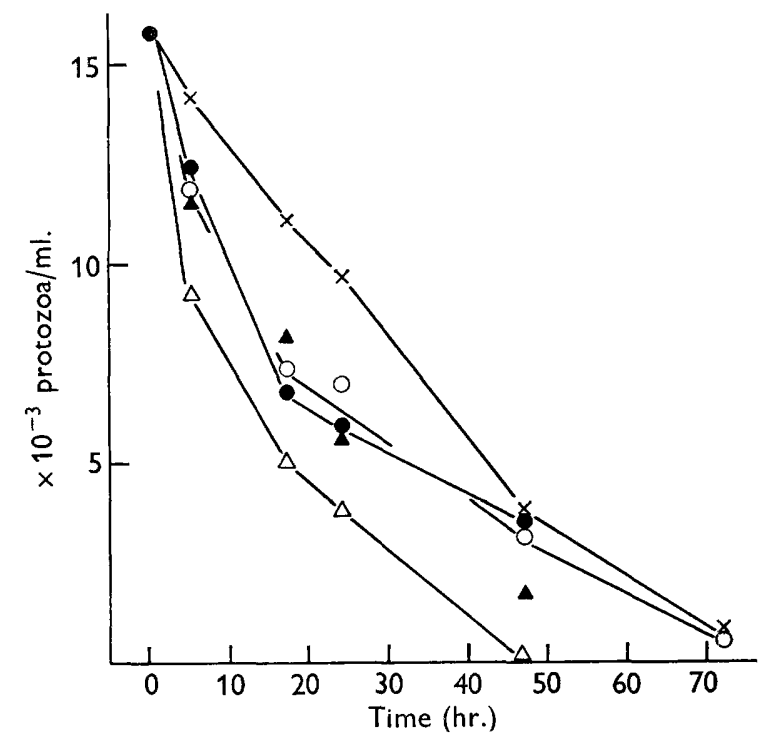

Fig. 3. Effect of various carbohydrates on the survival of starved 'bacteria-free' protozoa. $\triangle$, no added carbohydrate; $\times, 0.8 \%(\mathrm{w} / \mathrm{v})$ soluble $\operatorname{starch} ; \bullet, 0.08 \%(\mathrm{w} / \mathrm{v})$ rice starch grains; $0,1.6 \%(\mathrm{w} / \mathrm{v})$ maltose; $\Delta, 1.6 \%(\mathrm{w} / \mathrm{v})$ glucose. 
inoculation of the first incubation medium only $5 \mathrm{mg}$. rice starch was added to each inoculum culture and the rice star $2 h$ grains in the first incubation were replaced by $0 \cdot 2$ g. soluble starch in each $15 \times 2 \cdot 2 \mathrm{~cm}$. tube. These protozoa died at 2-10 times the usual rate when incubated in the absence of carbohydrate and contained no material which stained blue with iodine. The rate at which the protozoa died was decreased by adding several carbehydrates of which soluble starch was the most effective, followed by maltose and glucose; fructose and the fructose polysaccharide inulin were relatively ineffective ( $\mathrm{T}$ able 4 ). There was considerable variation between experiments in the relative effectiveness of these various materials; the figures quoted are averages. Figure 3 shows that the stimulatory effect also varies with time.

\section{DISCUSSION}

As far as the author is aware the present work represents the first successful attempt to prepare bacteria-free Entodinia where several media designed to detect rumen bacteria have been used. There is disagreement over the best type of medium for the growth of rumen bacteria. Wilson \& Briggs (1955) reported that a rich broth (reinforced clostridial medium) gare the best results of nine media tested, whereas Bryant \& Burkey (1953) favoured a poor medium containing a high concentration of autoclaved rumen fluid. Media based on these two types have been tested and the high rumen fluid medium gave tre highest results from antibiotic-treated suspensions; King \& Smith (1955) obtained similar results with fresh rumen contents. In view of the present findings, it is considered that the two reports of bacteria-free Entodinium spp. in the literature are of doubtful validity. Abou Akkada \& Howard (1960) treated Entodinium caudatum suspensions with chloramphenicol and found no bacteria able to grow in a semi-solid thioglycollate starch medium. This medium is similar, except that glucose was replaced by starch, to the fluid thioglycollate medium used in the present experiments, and in penicillin + streptomycin treated cultures counts of $10^{6}$ bacteria $/ \mathrm{ml}$. were obtained on medium $\mathrm{C}$ and $0-10^{2} / \mathrm{ml}$. on the fluid thioglycollate medium. It is essential to carry out all tests for viable bacteria on at least one aerobic and one anaerobic medium and that various standard media should be tested to enable the best to be selected.

The absence of any stimulatory effect of ordinary culture medium constituents on 'bacteria-free' protozoa under standard conditions is in contrast to the results reported previously (Coleman, 1950 b) where penicillin-treated Entodinia were stimulated by the addition of yeast extract and dried grass. These cultures are now known to have contained more bacteria (Table 1) than at first reported and it is likely that the effect of these additives was indirect and was the result of bacterial metabolism.

In previous experiments (Coleman, 1958, 1960a) carried out in the presence of bacteria the only source of carbohydrate that produced growth and division was intact rice starch grains. It is likely that only by the use of a solid food material, which was engulfed by the protozoa, was it possible to supply utilizable carbohydrate without extensive bacterial breakdown and acid production before assimilation by the protozoa. In the present experiments where starved 'bacteria-free' protozoa have been produced, an effect of soluble starch and, more important, of glucose and maltose on the survival of the protozoa was found for the first time. The apparent inability of Entodinium sp. to utilize soluble carbohydrates has for long 
been in contrast to the rapid utilization of sugars, especially glucose, by Holotrich protozoa (Oxford, 1951, 1955).

I wish to thank Mr R. B. Taylor, who fistulated the sheep used in this work; Dr M. P. Bryant for giving me the details of his improved culture medium before publications, and Miss J. M. How and Miss J. G. Pearson for their valuable technical assistance.

\section{REFERENCES}

Aвou Akrada, A. R. \& Hownkd, B. H. (1960). The biochemistry of rumen protozoa. 3. The carbohydrate metabolism of Entodinium. Biochem. J. 76, 445.

Bryant, M. P. \& Burkey, L. A. (1953). Cultural methods and some characteristics of some of the more numerous groups of bacteria in the bovine rumen. J. Dairy Sci. 36, 205.

Bryant, M. P. \& Robinson, I. M. (1961). An improved non-selective culture medium for ruminal bacteria and its use in determining diurnal variation in numbers of bacteria in the rumen. J. Dairy Sci. 44, 1446.

Coleman, G. S. (1958). Maintenance of oligotrich protozoa from the sheep rumen in vitro. Nature, Lond. 182, 1104.

Coleman, G. S. $(1960 a)$. The cultivation of sheep rumen oligotrich protozoa in vitro. J. gen. Microbiol. 22, 555 .

Coleman, G. S. $(1960 b)$. Effect of penicillin on the maintenance of rumen oligotrich protozoa. Nature, Lond. 187, 518.

Conlrss, J. O. (1959). An illustrated key to the higher groups of the ciliated protozoa, with definition of terms. J. Protozool. 6, 265.

King, K. W. \& Sмiтh, P. H. (1955). Comparisons of two media proposed for the isolation of bacteria from the rumen. J. Bact. 70, 726.

Mrak, E. M. \& Phaff, H. J. (1948). Yeasts. Annu. Rev. Microbiol. $2,1$.

OXFord, A. E. (1951). The conversion of certain soluble sugars to a glucosan by holotrich ciliates in the rumen of sheep. J. gen. Microbiol. 5, 83.

Oxford, A. E. (1955). The bacteriology and protozoology of ruminant digestion. J. Sci. Food Agric. 6, 413.

Oxford, A. E. (1958). Bloat in cattle. 9. Some observations on the culture of the cattle rumen ciliate Epidinium ecaudatum (Crawley) occurring in quantity in cows fed on red clover (Trifolium pratense L.) N.Z. J. Agric. Res. 1, 809.

Stone, H. W. \& Beeson, C. (1936). Preparation and storage of standard chromous sulphate solution. Industr. Engng Chem. (Anal.), 8, 188.

SUGDEN, B. (1953). The cultivation and metabolism of oligotrich protozoa from the sheep's rumen. J. gen. Microbiol. 9, 44.

WEGNER, G. H. \& Foster, E. M. (1960). Fatty acid requirements of certain rumen bacteria. J. Dairy Sci. 43, 566.

Wilson, M. K. \& Briggs, C. A. E. (1955). The normal flora of the bovine rumen. 2. Quantitative bacteriological studies. J. appl. Bact. 18, 294. 